\title{
PASTURE IMPROVEMENT AND POTENTIAL PRODUCTIVITY IN SOUTHERN NORTH ISLAND HILL COUNTRY
}

\author{
D. A. Grant, P. J. Rumball and F. E. T. Suckling \\ Grasslands Division, DSIR, Palmerston North, Kaikohe, and
}

Palmerston North

HILL COUNTRY is characterized by its steep slopes, differences in aspect, and variability in microtopography. The soils are often shallow, and erosion through slipping and slumping a serious problem. Because of the steepness of slope, most hill country cannot be cultivated and improvement' must be brought about by oversowing and other management practices. New Zealand is characterized by such country throughout its length. However, this discussion will be limited to hill country located in the mild, humid areas comprising the southern half of the North Island.

Soils of this hill country area are largely central yellow-brown earths and related steepland soils with intergrades into central yellow-grey earths and central yellow-brown loams. Fertility varies considerably depending on slope, parent material, rainfall and previous forest cover. Levels of fertility as determined by parent material are higher on siltstones and mudstones, moderate in some soils from argellite and greywacke, and low in soils derived from coarse sandstones. However, phosphate is universally limiting, $\mathrm{pH}$ is generally low and, on more leached soils, plantavailable molybdenum is low (N.Z. Soil Bureau, 1968). Low sulphur levels have also been reported (Blackmore et al., 1969).

\section{PRODUCTIVITY OF UNIMPROVED PASTURE}

The yield of unimproved Manawatu hill country pasture at Te Awa is about $5600 \mathrm{~kg} \mathrm{DM} / \mathrm{ha} /$ year, capable of supporting 7.5 ewe equivalents/ha. Under local farming conditions, however, only 3.5 to 4.0 ewes/ha are carried on unimproved pasture, the difference reflecting the increase that can be achieved through full utilization of herbage produced (Suckling, 1954).

Yates (1971) found unimproved hill country at Makara produced an average of $2700 \mathrm{~kg} \mathrm{DM} / \mathrm{ha} /$ year carrying 4.3 or 5.8 ewe equivalents depending on whether the grazing was lax or hard, respectively. 
TABLE 1: EFFECTS OF HILL PASTURE IMPROVEMENT ANIMAL PRODUCTIVITY

N.Z. farm production statistics, 1950-1 to 1967-8

\begin{tabular}{|c|c|c|c|}
\hline County & $\begin{array}{c}\text { Ewe Equiv./ } \\
\text { Grassed ha } \\
\text { 1950-I }\end{array}$ & $\begin{array}{c}\% \text { Grassed } \\
\text { Area Topdressed } \\
\text { by Air } 1967-8\end{array}$ & $\begin{array}{c}\text { E we Equiv./ } \\
\text { Grassed ha } \\
\text { 1967-a }\end{array}$ \\
\hline $\begin{array}{l}\text { Taumarunui- } \\
\text { Waitomo } \\
\text { Waiapu } \\
\text { Wairoa } \\
\text { Akitio }\end{array}$ & $\begin{array}{l}8.2 \\
4.9 \\
6.7 \\
5.4 \\
-\end{array}$ & $\begin{array}{l}62 \\
21 \\
35 \\
51\end{array}$ & $\begin{array}{r}12.1 \\
7.4 \\
9.6 \\
10.1 \\
-\end{array}$ \\
\hline \multicolumn{4}{|c|}{ Campbell (1965) } \\
\hline Farm Location & $\begin{array}{c}\text { Est. Potential } \\
\text { Ewes/ha } \\
19.54\end{array}$ & $\begin{array}{l}\text { Superphosphate } \\
\text { Total Applied } \\
(\mathrm{kg} / \mathrm{ha})\end{array}$ & $\begin{array}{l}\text { Ewe Equrv, jha } \\
\text { after Topdressing } \\
\text { (1964) }\end{array}$ \\
\hline $\begin{array}{c}\text { Hawke's Bay } \\
\text { Hawke's Bay } \\
\text { Dannevirke } \\
\text { Masterton }\end{array}$ & $\begin{array}{c}1.2-7.4 \\
4.9 \\
7.4 \\
2.5-7.4\end{array}$ & $\begin{array}{r}500 \\
750 \\
1100 \\
1100\end{array}$ & $\begin{array}{r}8.4 \\
11.4 \\
14.6 \\
14.6\end{array}$ \\
\hline
\end{tabular}

Carrying capacities of the order quoted seem typical of hill country pastures prior to aerial topdressing.

The effects of hill pasture improvement on animal productivity are shown in Table 1.

It is apparent from the variability of the data that a considerable range in productivity existed, a reflection of many factors, including variability in soil fertility, sociological and economic conditions.

\section{THE IMPROVEMENT PROCESS}

The basis of increasing pasture yield and quality has been the introduction to the sward of a vigorous legume, usually white clover, but often in areas where summer droughts are a problem subterranean clover is used more effectively. Lotus species may be important in wetter environments.

These legumes, when associated with an effective rhizobium strain, provide the nitrogen necessary for pasture growth. Vigorous legume growth and hence increased rates of $\mathrm{N}$ fixation require the correction of nutrient deficiencies and imbalances characteristic of hill country soils. 
Since the advent and acceptance of aerial topdressing in the early 1950 s the majority of farmed hill country in the southern North Island has been improved to some degree through the introduction of legumes and addition of superphosphate and molybdenum where necessary.

Two approaches have been used in applying superphosphate for improvement of hill pasture. In one case the steady application of low rates of superphosphate at 100 'to $250 \mathrm{~kg} / \mathrm{ha} /$ year, often over only half the farm, is practised. More recently a crash programme is frequently adopted whereby 700 to $1100 \mathrm{~kg}$ is applied in the first six months of the programme followed by an annual maintenance of $250 \mathrm{~kg}$. Jackman et al. (1962) estimated 55 to $70 \mathrm{~kg} / \mathrm{ha}$ of phosphorus (550 to $700 \mathrm{~kg} / \mathrm{ha}$ superphosphate) were necessary to overcome initial phosphate limitations on unimproved yellow-brown earths.

For many hill soils and most steepland soils, little is known about the quantities of lime and superphosphate needed initially, or for maintenance, to achieve any given level of pasture production (During, 1967). The fact that a complex of limiting, factors could be involved should also be appreciated.

Trials by Blackmore et al. (1969) indicate that application of up to $90 \mathrm{~kg}$ phosphorus/ha produced responses, based on estimates of clover vigour, of more than $100 \%$. Up to $50 \mathrm{~kg}$ sulphur/ ha gave responses of 30 to $100 \%$ and $2500 \mathrm{~kg}$ lime up to $30 \%$. The trials were located in the Wanganui-Rangitikei district'on a suite of central YBE steepland soils with integrades to YGE soils.

Little seems to have been done to remedy the acidity of many hill country soils. Thus, low $\mathrm{pH}$ and the nutrient' imbalances resulting from this, especially increased solubilities of $\mathrm{Al}$ and $\mathrm{Mn}$, may be major limiting factors to improvement at present since legumes are particularly susceptible to such imbalances.

The scale of improvement on hill country, and its effects, can be estimated. Approximately 2.2 million hectares of the North Island are now topdressed by air with an average of $300 \mathrm{~kg} / \mathrm{ha}$ superphosphate (N.Z. Farm Prod. Stats. 1967-g). This represents about $50 \%$ of the North Island hill country area as quoted by Levy (1970) or $65 \%$ of the 3.4 million hectares of North Island hill country estimated by Gibbs (1963) as having pastoral potential. Within this area some predominantly hill country districts have a much lower proportion being aerially topdressed - e.g., only $21 \%$ of the East Coast county of Waiapu.

In the 20 years of aerial topdressing it is estimated from aerial fertilizer application figures (N.Z. Farm Prod. Stats., 1950-1 
et seq.) that, on average, North Island hill country would have received a total of $1400 \mathrm{~kg} / \mathrm{ha}$ of super-phosphate and from data available it is apparent that carrying capacities of predominantly hill country counties and the farms surveyed by Campbell (1965) have increased 50 to $100 \%$ in this time (see Table 1). Although the relationship is unlikely to be simple and direct, this increased carrying capacity must be attributed largely to the improvement process.

\section{PRODUCTIVITY OF IMPROVED PASTURE}

Suckling (1959) found that improvement resulted in pasture productivity increasing from $5600 \mathrm{~kg}$ DM/ha to 9200 on hillsides with a resultant increase in carrying capacity of 6.5 ewe equivalents/ha. Similar results have been noted by Yates (1971) see Table 2. As seen in Table 1 these are the levels of stocking rate, and therefore presumably pasture yield, which the. more productive farms quoted by Campbell (1965) have achieved. Even some county averages such as that for Taumarunui-Waitomo are approaching these figures.

TABLE 2: EFFECTS OF HILL PASTURE IMPROVEMENT PASTURE PRODUCTIVITY

(Suckling, 1959; Yates, 1971)

\begin{tabular}{lcccc}
\hline & $\begin{array}{c}\text { Pasfure Prod. } \\
\text { Source }\end{array} \mathbf{( k g} D$ DM/ha/yr) & $\begin{array}{c}\text { Ewe } \\
\text { Equiv./ha }\end{array}$ & $\begin{array}{c}\text { Improved } \\
\text { Pasture Prod. } \\
(\mathrm{kg} D M / h a / y r)\end{array}$ & $\begin{array}{c}\text { Ewe } \\
\text { Equiv./ha }\end{array}$ \\
\hline $\begin{array}{l}\text { Suckling (1959) } \\
\text { Yates (1971) : }\end{array}$ & 5600 & 7.4 & $9000-9500$ & 13.8 \\
Hard grazed & 2700 & & & \\
Lax grazed & 2700 & 5.8 & 8600 & 12.8 \\
\hline
\end{tabular}

Suckling (1962) further increased pasture productivity to an average of $11500 \mathrm{~kg} \mathrm{DM} / \mathrm{ha} /$ year on hillsides by applying two annual dressings each of $750 \mathrm{~kg} / \mathrm{ha}$ superphosphate and then reverting to the former rate of $250 \mathrm{~kg}$. Stocking rate rose from 12.4 to 17.3 ewes/ha, per-animal productivity increasing slightly also.

There are no data available to indicate what number of hill country farms, if any, have achieved this level of productivity successfully. The average county carrying capacities quoted earlier appear to be about half, or less, that achieved by Suckling on his most intensive treatments, 


\section{PASTURE SPECIES AND IMPROVEMENT}

Unimproved hill country pastures in the southern North Island are characterized by the dominance of a tight mat of grasses, principally browntop, typical of pastures on infertile soils. Tiller numbers of such swards often exceed $330 / \mathrm{dm}^{2}$ in comparison with the $80 / \mathrm{dm}^{2}$ characteristic of dairy pastures (Mitchell and Glenday, 1958). Swards are characterized also by the lack of legumes and by many flat weeds (Madden, 1940).

\section{TABLE 3: EFFECTS OF HILL PASTURE IMPROVEMENT — PASTURE COMPOSITION (Suckling, 1959)}

\begin{tabular}{lccc}
\hline & \multicolumn{2}{c}{ Hits/100 pts } & Improved \\
& Unimproved & Improved & Stock Camp \\
\hline Perennial ryegrass & 7 & 31 & 72 \\
Browntop & 35 & 34 & 9 \\
Yorkshire fog & 12 & 13 & 33 \\
Crested dogstail & 5 & 24 & 6 \\
Sweet vernal & 14 & 8 & 5 \\
White clover & 7 & 34 & 24 \\
Catsear & 18 & 5 & 2 \\
Bare ground & 18 & 2 & - \\
\hline
\end{tabular}

From Table 3 it can be seen that improvement, besides increasing pasture yield, has resulted in significant changes in botanical composition, particularly an increased cover of white clover, crested dogstail and perennial ryegrass, a species normally associated with high fertility conditions. Brougham and Grant (unpubl.), in a survey of Manawatu hill pastures, found white clover was widespread, the average frequency of occurrence in tiller plugs being $50 \%$ in summer. However, improvement may be limited in some areas of the Wairarapa where clover establish-, ment and inoculation problems have been indicated (Booth and Gibbs, 1969).

Changes are even more pronounced under stock camp conditions, especially the increase in perennial ryegrass ground cover.Yorkshire fog also increases in ground cover under these conditions and the cover from browntop is greatly reduced (Table 3 ).

During (1967) \&tributes the delayed response to fertilizer on some hill pastures to the influence of the mat of low fertility grasses inhibiting clover vigour. On the same soils, following over-' sowing after a scrub bum, responses are rapid. Suckling (1960)' 
TABLE 4: SPECIES PRODUCTIVITY

(Suckling, 1960)

\begin{tabular}{|c|c|c|c|c|c|c|}
\hline & & & & & \multicolumn{2}{|c|}{$k g D M / h a / y r$} \\
\hline Perennial ryegrass & & & 111 & $\ldots$ & , & 26600 \\
\hline Red clover (Montgomery) & & . & $\mathrm{rm}$ & 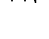 & & 26400 \\
\hline Cocksfoot & . & & . & & . & 22000 \\
\hline Plantain (narrow-leaved) ${ }^{“ "}$ & $\ldots$ & $\cdots$ & & & $\ldots$ & 20600 \\
\hline Yorkshire fog & & & & & & 15800 \\
\hline Chewing's fescue & & $\ldots$ & & $\ldots$ & & 14700 \\
\hline Catsear . ...' & & & & & & 13500 \\
\hline Danthonia pilosa & & & & & & 11400 \\
\hline White clover & & & & . & . & 10500 \\
\hline Sweet vernal & & & . & . & & 9800 \\
\hline Browntop & & & & . & $\cdots$ & 8500 \\
\hline $\mathrm{Cr}$ e s t e d dogstail $\ldots .$. & . & $\ldots$ & & & $\ldots$ & 7300 \\
\hline
\end{tabular}

found considerable differences in production between species under high fertility hill country conditions (Table 4).

Thus there appears good reason for attempting to change the grass components of hill pasture to increase yield and response to topdressing. However, Suckling (1954) reports the failure of an attempt to oversow high fertility grasses into a poor hill country sward following pre-treatment with stock. Attempts at renovation of hill pastures using paraquat and oversowing are temporarily successful but Ayson (1968) reports that rapid reversion usually occurs. One suspects that species are being introduced into conditions where soil fertility is insufficient to allow vigorous growth and maximum competitive ability. As Suckling's work has indicated, the changes in pasture composition towards more desirable species tend to occur naturally as the succession proceeds through increasing planes of fertility,

\section{SEASONAL PRODUCTION AND PASTURE QUALITY FOLLOWING} IMPROVEMENT

Seasonal distribution of production and feed quality are important factors which tend to be overlooked when considering pasture yield alone. Traditionally, winter is the period of severe feed shortage in hill country and livestock numbers tend to be determined by what can be fed through the winter. Current trials on hill country indicate that, as total production increases with improvement, so does the proportion of herbage production during the winter months — see Table 5 (Grant, unpubl.) . 
TABLE 5: SEASONAL PRODUCTION (Grant, unpubl.)

\begin{tabular}{ccccc}
\hline \multirow{2}{*}{ kg DM /ha } & Dec.-Feb. & Mar.-May & May-Aug. & Sep.-Dec. \\
\hline 5600 & 43 & 14 & 3 & 40 \\
11800 & 28 & 16 & 8 & 48 \\
15100 & 29 & 15 & 13 & 44 \\
\hline
\end{tabular}

With improvement, crude protein content has been found to increase from 12 to $21.5 \%$. The contribution of clovers to dry matter production increased from 2 to $6 \%$. These changes were apparent as a shift from short, hard feed with a high content of dead leaf and stem to a more succulent, rapidly-grown herbage (Suckling, 1964) .

\section{POTENTIAL PRODUCTION OF HILL COUNTRY}

The production potential of hill pasture is probably achieved on some stock camps. These are limited areas of low slope selected by the grazing animals as resting spots. Dung and urine deposits cause unusually high levels of soil fertility, particularly in available phosphorus and potassium (Radcliffe, 1968). Such areas yield between 13000 and $28000 \mathrm{~kg}$ DM/ha/year after improvement. Even under unimproved conditions, the range of productivities on stock camps was little less - 10000 to 25000 $\mathrm{kg} \mathrm{DM} /$ ha/year (Suckling, 1959). For comparison, maximum productivity recorded on fertile Manawatu lowland soils from ryegrass/white clover swards was $19500 \mathrm{~kg}$ DM/ha/year without irrigation and 27000 with irrigation (Brougham, 1966). It is apparent that there is little difference in productivity between hill country stock camps and the maximum yield recorded from adjacent lowland pastures, and species composition is similar. The stock camp community arises through a succession from browntop dominance in response to increasing levels of fertility rather than being sown as on lowland.

Climate apparently affects both areas to a similar degree but possibly from different causes. Wind run in hill country can be $100 \%$ greater than in adjacent lowland (DSIR Grasslands Division Meteorological records). However, the altitude effects of lower temperature and more wind in hill country may be balanced by the increased rainfall (Geiger, 1966).

No precise data on the area of hill country made up by stock camps are available 'since any estimates of the proportion of hill 
country of low slope include stock tracks where fertility build-up is not as great (Radcliffe, 1968).

\section{SLOPE - THE COMPLICATING FACTOR}

The potential productivity of hillsides, by far the greatest area in hill country, may be much lower than the measurements obtained from stock camps on hill sites and on lowland pasture would indicate. The data already presented indicate that actual production on improved hillsides is about half that of stock camps in the same area.

It is believed that on hillsides the major limitation is slope. Slope increases the surface/map area ratio. This effect is compounded by the many variations in microtopography. For example, a hillside with an average slope of 29" has microsite slopes ranging from 0 to 80" (Grant, Brock, Ball, unpubl.) . Rumba11 (1966, unpubl.) found that a 35" slope had an actual surface area $30 \%$ greater than otherwise indicated. Thus stock carrying capacities on hill country may be considerably lower on an actual area basis than the figures quoted for plan areas.

Steep slopes have a high susceptibility to slip and slump erosion which directly reduces productivity by obliterating pasture. On some hill country the newly exposed parent material is of low fertility, which causes difficulty in re-establishing a productive pasture and increases the likelihood of scrub weed invasion. Susceptibility to slipping can be lowered by maintaining a vigorous pasture which results in a continuous cover and better soil structure (N.Z. Soil Bureau, 1968), and use of space-planted trees such as poplars. Most steepland soils tend to be shallow and, as a result, susceptible to summer drought (N.Z. Soil Bureau, 1968).

Because. of slope, aerial application is the only practical method of fertilizer distribution on hill country. However, Scott and Grigg (1970) suggest, that the unevenness of application inherent in this method reduces the effectiveness of superphosphate applied by 15 to $30 \%$ in comparison with the same quantity applied evenly. Slope itself may strongly influence the pattern .of distribution, pellets of fertilizer tending to bounce or be washed on to tracks to the detriment of bank areas.

Slope influences the behaviour of grazing animals on hillsides and this can directly effect productivity.

Steep bank areas that are grazed but, receive little dung or urine are depleted in fertility, while tracks and particularly camp 
areas are enriched (Radcliffe, 1968). Consequently it is felt that most pasture production on hillsides comes from these track areas and the drainage channels into which stock droppings and nutrients are washed by rain.

The behaviour pattern of animals on hillsides could be altered by intensive mob-stocking to force animals to move and deposit their dung and urine over a greater area of slope. Such rotational grazing may result in lower animal and pasture productivity, especially in the winter when tracks, the most productive areas, are bared of vegetation as a result of the restless behaviour of the animals (Suckling, 1959).

\section{SUMMARY AND CONCLUSIONS}

(1) The potential production of hill country pasture has probably been reached on stock camp areas.

(2) There appears little difference' between the yield on stock camps and the maximum yields recorded on lowland.

(3) The actual production of hill country on a county basis appears to be about half that already achieved by Suckling's most intensive treatments at Te Awa.

(4) This increased productivity was achieved by Suckling with the application of considerable quantities of additional superphosphate.

(5) On a broader scale, further knowledge is needed of the fertilizer requirements of many hill country soils, especially those of steeplands. In many instances a complex of nutrient deficiency and management factors probably affects production potential through limitations to legume growth. More information is therefore necessary before the most economic use of increased fertilizer is possible in many instances.

(6) In some instances delayed responses to fertilizer application have been attributed to the dominance of hill pasture by low fertility, mat-forming grasses. Composition of these pastures has seldom been successfully altered for long by such techniques as chemical renovation.

(7) Little can be done to alter the limitations of slope to hill country productivity other than adopting methods to maximize soil stability and possibly re-examining grazing methods to determine their effect on fertility re-distribution. 


\section{REFERENCES}

Ayson, E. C., 1968: Proceedings of the 21st N.Z. Weed and Pest Control Conference: $138-142$.

Blackmore, L. W.; Ludecke, T. E.; Hogg, D. E., 1969: Proceedings of the N.Z. Grassland Association, 31: 87-95.

Booth, A. K.; Gibbs, H. S., 1969: Proceedings of the N.Z. Grassland Association, 31: 9.

Brougham, R. W., 1966: N.Z. Agricultural Science, 2: 19-22.

Campbell, D. A., 1965: The sky's the limit. Aerial mechanization of pasture improvement and soil conservation in New Zealand. Soil Conservation and Rivers Control Council Bulletin 18.

During, C., 1967: Soils and Fertilisers in New Zealand Farming. Government Printer, Wellington. 322 pp.

Geiger, R., 1966: The Climate near the Ground. Harvard Univ. Press, Mass. (Trans. from 4th ed.)

Gibbs, H. S., 1963: Proceedings of the N.Z. Znsfitute of Agricultural Science, 9: 63-79.

Jackman, R. H.; During, C.; Andrews, E. D.; Lynch, P. B., 1962: Commissions IV and V. International Society of Soil Science Conference: 3-11.

Levy, E. B., 1970: Grasslands of New Zealand. Government Printer, Wellington. $374 \mathrm{pp}$.

Madden, E. A., 1940: N.Z. DSZR, Bulletin 79. pp.45.

Mitchell, K. J.; -Glenday, A. C,, 1958: N.Z. Journal of Agricultural Research, 1: 305-18.

New Zealand Soil Bureau, 1968: Soils of New Zealand. Part I. N.Z. Soil Bureau Bulletin 26 (1).

New Zealand Farm Production Statistics. Government Printer, Wellington.

Radcliffe, J. E., 1968: N.Z. Journal of Agricultural Research, 11: 359-70.

Scott, R. S.; Grigg, J. L., 1970: N.Z. Journal of Agricultural Research, 13: $12-32$

Suckling, F. E. T., 1954: N.Z. Journal of Science and Technology, 36A: 237-73.

1959: N.Z. Journal of Agricultural Research, 2: 488-548.

1960: N.Z. Journal of Agricultural Research, 3: 579-91.

1962: Sheepfarming Annual: 181-97.

1964: Proceedings of the N.Z. Grassland Association: 137-52.

Yates, M. E., 1971: Journal of Hydrology (New Zealand), 10: 59-84. 